OPEN ACCESS

Edited by:

Stuart G. Tangye,

Garvan Institute of

Medical Research, Australia

Reviewed by:

Jane Oliaro,

Peter MacCallum

Cancer Centre, Australia

Tri Giang Phan,

Garvan Institute of Medical

Research, Australia

*Correspondence:

Emily M. Mace

mace@bcm.edu

Specialty section:

This article was submitted to Primary Immunodeficiencies,

a section of the journal

Frontiers in Immunology

Received: 15 January 2018 Accepted: 19 February 2018

Published: 07 March 2018

Citation:

Mace EM (2018) Phosphoinositide-

3-Kinase Signaling in Human Natural Killer Cells: New Insights from Primary Immunodeficiency.

Front. Immunol. 9:445. doi: 10.3389/fimmu.2018.00445

\section{Phosphoinositide-3-Kinase Signaling in Human Natural Killer Cells: New Insights from Primary Immunodeficiency}

\author{
Emily M. Mace* \\ Department of Pediatrics, Baylor College of Medicine, Center for Human Immunobiology, Texas Children's Hospital, \\ Houston, TX, United States
}

Human natural killer (NK) cells play a critical role in the control of viral infections and malignancy. Their importance in human health and disease is illustrated by severe viral infections in patients with primary immunodeficiencies that affect NK cell function and/ or development. The recent identification of patients with phosphoinositide-3-kinase (PI3K)-signaling pathway mutations that can cause primary immunodeficiency provides valuable insight into the role that PI3K signaling plays in human NK cell maturation and Iytic function. There is a rich literature that demonstrates a requirement for PI3K in multiple key aspects of NK cell biology, including development/maturation, homing, priming, and function. Here, I briefly review these previous studies and place them in context with recent findings from the study of primary immunodeficiency patients, particularly those with hyperactivating mutations in $\mathrm{PI} 3 \mathrm{~K} \delta$ signaling.

Keywords: phosphoinositide-3-kinase signaling, primary immunodeficiency, natural killer cell biology, human natural killer cells, natural killer cell development, natural killer cell cytotoxicity

\section{INTRODUCTION}

\section{Human Natural killer (NK) Cell Development, Lytic Function, and Migration}

Human NK cells are derived from bone marrow precursors and mature in the peripheral tissues, particularly the secondary lymphoid tissue (1-3). Their development can be defined by select cell surface receptor and transcription factor expression in combination with increasingly restricted lineage potential of developmental intermediates (4). Despite an increasing understanding of the relationship between NK cells and other innate lymphoid cell subsets, however, the exact nature of the steps of NK cell development is incompletely understood. This likely reflects the importance of the local microenvironment in tuning NK cell development and plasticity of NK cell developmental intermediates, as discrete tissue sites have unique resident NK cell populations (1).

Within peripheral blood, human NK cells comprise approximately $10 \%$ of lymphocytes and are broadly classified as $\mathrm{CD} 56^{\text {bright }}$ or $\mathrm{CD} 56^{\mathrm{dim}}$, two subsets with distinct phenotypic and functional properties (5). CD56 $6^{\text {bright }}$ are considered less mature than the CD56 ${ }^{\mathrm{dim}}$ subset, and their lesser frequency within peripheral blood is converse to their predominance in the secondary lymphoid tissue, where they are thought to develop (6). CD56 ${ }^{\mathrm{dim}} \mathrm{NK}$ cells are cited as having the greatest capacity for lytic function; however, similar capacity for lytic function can be elicited from CD56 bright NK cells with cytokine priming or activation $(5,7-10)$. CD56 $6^{\text {bight }}$ cells are strong producers of 
cytokines, particularly IFN $\gamma$ and TNF $\alpha$ and are frequently considered more immunoregulatory than CD56 ${ }^{\mathrm{dim}} \mathrm{NK}$ cells. In addition, CD56 ${ }^{\mathrm{dim}} \mathrm{NK}$ cell subsets can be further dissected to terminally mature subsets that can include adaptive NK cells with memory-like function for rapid response to previously encountered antigen (11-17).

Natural killer cell lytic function is mediated through the formation of an immunological synapse, a specialized signaling platform that directs the secretion of specialized secretory lysosomes containing perforin and granzymes $(18,19)$. Many of the steps leading to the formation of an NK cell lytic immunological synapse are common to other immunological synapses, including $\mathrm{T}$ cell synapses (20). There are also distinct features of the NK cell immunological synapse that are likely a function of unique mechanisms of NK cell activation and sensing, as NK cells use germline-encoded activating and inhibitory receptors to integrate signals that can lead to lysis of non-self, stressed, transformed, or virally infected cells (21). While an in-depth description of this process is beyond the scope of this review, key events in this process include firm adhesion to a target cell, actin polymerization and reorganization at the immunological synapse, lytic granule convergence, microtubule-organizing center (MTOC) (and lytic granule), polarization toward the synapse, granule exocytosis, and termination of the immunological synapse following target cell death (22). Relative to lytic synapses formed by cytolytic effector $\mathrm{CD}^{+} \mathrm{T}$ cells, NK cell lytic synapses are less rapidly formed and seemingly have a greater number of regulated steps to cytotoxicity, likely due to their non-antigen-restricted mechanism of sensing target cells and "missing-self" recognition (21). Their capacity for autologous killing is restrained by a process termed licensing, in which NK cells are licensed for lytic potential through the engagement of inhibitory receptors with self-MHC class I (23-25). While the molecular mechanisms of licensing are not fully understood, this process is reversible, and even unlicensed cells ultimately have the potential to be fully lytic (26-29). Through an understanding of licensing, priming, and cytokine-induced memory, it seems that NK cell function can be tuned for responsiveness through multiple mechanisms.

While less understood at a molecular level than immunological synapse formation, NK cell migration and homing are intrinsic components of both development and function. The accepted paradigm of NK cell development suggests that NK cells enter circulation to traffic to tissue at both an early developmental stage and ultimately as terminally mature cells. Intravital imaging of mouse lymph nodes demonstrates that NK cells patrol the $\mathrm{T}$ cell zone and make transient, yet direct, contacts with dendritic cells and $\mathrm{T}$ cells (30-32). This significant migratory behavior has obviously not been directly visualized in human tissue; however, human NK cells undergo spontaneous migration on developmentally supportive stromal cells (33). This intrinsic migratory capacity can be recapitulated by the differentiation of NK cells in vitro, and developmental intermediates have intermediate migratory phenotypes $(33,34)$. In the context of lytic function, NK cell migration plays a key role in the serial killing capacity of activated cells, which often kill up to 10 sequential targets (35-40). Activated NK cells have a more dynamic migration, with modes of migration that are distinct from resting cells (40). This includes a more motile scanning of targets, a specifically greater directional persistence, less time spent in arrest, and a greater migration speed. These changes in migration mode have been described between resting and cytokine-activated (40), or unlicensed and licensed human NK cells (39), suggesting a link between multiple forms of activation and changes in migratory phenotype; however, the mechanism by which these changes are induced is unknown.

Human primary immunodeficiency is a powerful model to determine the requirements for human NK cell function and development. In particular, studies of patients with WiskottAldrich syndrome $(41,42)$, MyH9-related disorders $(43,44)$, DOCK8 deficiency (45), and Coronin 1A deficiency (46) have led to the definition of these as critical mediators of NK cell immune synapse formation and function and defined the molecular basis of their function in a uniquely human setting. A similar approach can be taken to determine the requirements for human NK cell development through the study of patients with NK cell deficiency as a result of loss of NK cells or NK cell subsets in peripheral blood [reviewed in Ref. $(47,48)$ ]. In particular, a decreased frequency of the CD56 ${ }^{\mathrm{dim}}$ subset has been used as a readout for the impaired terminal maturation of NK cells. Using this approach, unexpected requirements for the eukaryotic DNA helicase complex components MCM4 and GINS1 specifically in NK cell development have been identified (49-51). Similarly, biallelic mutations in IRF8 lead to specific loss of the CD56 dim subset, with accompanying severe viral susceptibility in affected patients (52), and RTEL1 mutations can lead to the absence of NK cells in peripheral blood $(53,54)$. More puzzling are mutations in GATA2, which lead to specific loss of the CD56 $6^{\text {bright }}$ subset with variable effects on absolute NK cell frequencies, although this effect may be due to depletion of all but adaptive NK cells in affected patients (55-58).

Cases of isolated NK cell deficiency, in which NK cells are the primary or only affected immunological subset, are relatively rare. However, the extreme susceptibility of these patients to viral infections, particularly of the herpesvirus family, underscores the importance of NK cells in human health and disease $(47,48)$. Much more common are primary immmunodeficiencies that may include deregulated NK cell function or phenotype as part of their spectrum of disease. These can be illustrative of requirements for NK cell development or function, despite involvement of other immune compartments. These primary immunodeficiencies that affect NK cells range from severe combined immune deficiency as a result of IL2RG (59) or JAK3 (60) mutation, which defines the requirement for common gamma chain cytokine signaling in human NK cell development, to diseases including STAT1 gain-of-function (GOF) mutations (61) and STAT3 deficiency (62). In each of these cases, it is important to consider that other affected immune compartments can also impact NK cell phenotype and function. It can also be difficult to delineate between primary immmunodeficiencies that seemingly lead to a "hard stop" in NK cell maturation, such as MCM4 and GINS1 deficiencies and those that deregulate specific receptor expression or aspects of homeostasis, such as STAT1 GOF mutations. Regardless, in each case, the phenotype of deregulated NK cell 
development is accompanied by an effect on NK cell function that translates to susceptibility to infection and, in some cases, malignancy. Moving forward, however, it will be important to recognize these distinctions through the careful definition of what truly phenotypically and functionally defines NK cells and their subsets. In addition, determining the NK cell-intrinsic component to these mutations, such as by cell line modeling, is important for the proof of concept to define a particular gene as being required for human $\mathrm{NK}$ cell function.

The phosphoinositide-3-kinase (PI3K)-signaling axis plays a key role in a multitude of cellular functions. It is increasingly being recognized for its importance in the control of inflammation and cancer and is a particularly exciting target for new small molecule inhibitors designed to modulate its key players. Given its ubiquitous expression, perturbations in this pathway are predicted to impact a number of cellular functions. However, there are specific requirements for PI3K signaling in NK cell function, the importance of which are underscored by model organisms and recently described human mutations in PIK3CD that lead to significant defects in NK cell maturation and function (Table 1).

\section{PI3K Signaling in Human NK Cells}

Class IA PI3K are heterodimeric enzymes that consist of a regulatory p 85 subunit and a catalytic $\mathrm{p} 110 \alpha,-\beta$, or $-\delta$ subunit; class $1 \mathrm{~B}$ $\mathrm{PI} 3 \mathrm{~K}$ is composed of the $\mathrm{p} 110 \gamma$ subunit and p101 or $\mathrm{p} 84$ regulatory subunit. While all PI3K isoenzymes play a key role in catalyzing the production of PtdIns $(3,4,5) \mathrm{P} 3$ from $\operatorname{PtdIns}(4,5)$ $\mathrm{P} 2$, evidence suggests that they have unique functions (81). In addition, while $\mathrm{p} 110 \alpha$ and $\mathrm{p} 110 \beta$ are widely expressed, $\mathrm{p} 110 \gamma$ and $\mathrm{p} 110 \delta$ expression is primarily restricted to lymphocytes. Activating signaling leads to PI3K-mediated generation of PtdIns $(3,4,5)$ $\mathrm{P} 3$, the accumulation of which in the cell membrane provides a platform for pleckstrin homology $(\mathrm{PH})$-domain-containing proteins, including AKT, phosphoinositide-dependent kinase-1 (PDK1), and Tec family kinases such as BTK. This pathway is additionally regulated by phosphatases including phosphatase

TABLE 1 | Effect of phosphoinositide-3-kinase (PI3K) mutations relevant to activated PI3K delta syndrome on natural killer (NK) cell development and function.

\begin{tabular}{llllc}
\hline Gene (protein) & $\begin{array}{l}\text { Mutation } \\
\text { type }\end{array}$ & $\begin{array}{l}\text { NK } \\
\text { function }\end{array}$ & $\begin{array}{l}\text { NK number/ } \\
\text { phenotype }\end{array}$ & Reference \\
\hline Human & & & & \\
PIK3CD (p1108) & GOF & Impaired & Decreased/affected & $(63-67)$ \\
PIK3CD (p1108) & LOF & ND & ND & $(68)$ \\
PIK3R1 (p85 $\alpha)$ & GOF & ND & Decreased/ND & $(69)$ \\
PIK3R1 (p85 $\alpha)$ & LOF & ND & Decreased & $(70)$ \\
PTEN (PTEN) & LOF & ND & Decreased/ND & $(71-73)$ \\
PTEN (PTEN) & OE & Decreased & ND & $(74)$ \\
\hline Mouse & & & & $(75,76)$ \\
Pik3cd (p1108) & Deletion & Impaired & Decreased/affected & $(77)$ \\
Pik3cd (p1108) & Inactive & Impaired & Decreased/affected & $(78)$ \\
Pik3r1 (p85 $\alpha)$ & Deletion & Impaired & Decreased/affected & $(79)$ \\
PTEN (PTEN) & Deletion & Impaired & Increased/affected & $(80)$ \\
Inpp5d (SHIP-1) & Deletion & $\begin{array}{l}\text { Decreased } \\
\text { (cytokine) }\end{array}$ & Decreased/affected & \\
PTEN (PTEN) & OE & Decreased & Unaffected & $(74)$ \\
\hline
\end{tabular}

$N D$, not determined; GOF, gain-of-function; LOF, loss of function; OE, overexpression. and tensin homolog (PTEN) and SH2-containing inositol phosphatase 1 (SHIP-1).

In human NK cells, the PI3K-signaling pathway plays a direct role in signaling downstream from activating receptors, including 2B4 and KIR receptors (82-84). The recruitment of p85, in combination with Grb2, is also necessary and sufficient for the propagation of signaling, leading to cytotoxicity downstream of NKG2D ligation association with the non-ITAM containing DAP10 adaptor (85-88). PI3K activity following recruitment to membrane proximal receptors leads to the production of PtdIns $(3,4,5) \mathrm{P} 3$ and the subsequent recruitment of PH domaincontaining proteins such as PLC $\gamma 1$, PLC $\gamma 2$, Vav1, and Tec kinases. Antibody-dependent cellular cytotoxicity (ADCC) is mediated by PI3K- and ITAM-dependent signaling by CD16 through FcyR and/or TCR $\zeta$ (89); PI3K signaling plays an additional role following Fc $\gamma \mathrm{R}$ ligation by activating ADP-ribosylation factor, which leads to PtdIns $(4,5) \mathrm{P} 2$ production by PI5K and phospholipase D activation (90).

Phosphoinositide-3-kinase activation and subsequent recruitment of PLC $\gamma 1$ and PLC $\gamma 2$ leads to mobilization of intracellular $\mathrm{Ca}^{++}$stores. In addition, PI3K activates a Rac1-MEK-ERK pathway that is a key signaling pathway for actin reorganization and cellular polarization (91). The central role of PI3K in mediating cell polarization can be defined by its control of Cdc42 activation at the NK cell immune synapse; in particular, p $85 \alpha$ acts as a scaffold to target and position PI3K and subsequently recruit guanine nucleotide exchange factors to the membrane (92). As such, the role of PI3K signaling in cytotoxicity and NK cell migration can be through the control of actin remodeling, polarization, and even granule exocytosis, which requires intracellular calcium store mobilization.

In addition to activating for cytotoxicity, PI3K plays a pivotal role in both priming and signaling downstream of cytokine activation. It is particularly important for the attenuation of signaling through IL-15, the critical NK cell development and survival cytokine (93). The activation of PI3K following IL-15 receptor ligation leads to the production of PtdIns $(3,4,5) \mathrm{P} 3$ and the recruitment of AKT to the cell membrane. AKT activation leads to survival and proliferation through the inhibition of pro-apoptotic Bcl2- and PDK1-dependent activation of mTOR, which promotes translation directly through the phosphorylation of S6 kinase and the initiation factor eIF4E-binding protein (94). In mice, PI3K-dependent PDK1 activation via IL-15 signaling may also directly help to direct NK cell lineage commitment through the induction of E4BP4 and Eomes, and PDK1-deficient mice have loss of NK cell cellularity and function (95).

The critical role of PI3K in JAK-STAT signaling makes it key in potentiating the effects of cytokine priming, in which the threshold for NK cell activation is lowered by stimulation with common gamma chain cytokines (IL-2, -15, -21) or IL-12 and IL-18 (96-98). The therapeutic potential of cytokine priming is highlighted by recent studies of human memory-like NK cells with enhanced lytic function that can be generated by cytokine priming and can be reactivated after even extended periods of rest (99-101). These cells are of extreme interest for immune therapy and also highlight the importance of cytokine priming in generating NK cells that can rise to further challenge (102). 
Physiologically, priming leads to an increased antitumor effect of NK cells, including an increased production of cytotoxic effector molecules, an increased conjugate formation with target cells, and an increased baseline activation of integrins (10). Interestingly, this effect in humans is primarily mediated by the CD56 $6^{\text {bright }} \mathrm{NK}$ cell subset, as opposed to CD56 ${ }^{\mathrm{dim}} \mathrm{NK}$ cells, which are traditionally considered the more cytolytic subset. Small molecule inhibition of the PI3K-signaling pathway blocks this priming effect and attenuates the antitumor response, underscoring its importance in modulating NK cell function $(10,103)$. The importance of the PI3K-signaling pathway in NK cell priming and its implication in NK cell licensing (104) underscore its importance as a master regulator of NK cell-functional capacity.

Finally, PI3K signaling is required for NK cell chemotaxis to chemokines including CC chemokine ligand (CC)L2, CCL5, CXCL10, and SDF1 $\alpha$ (105). While lymphocyte migration is thought to be mainly controlled by $\mathrm{p} 110 \gamma, \mathrm{p} 110 \delta$ is required specifically for chemotaxis mediated by the G-protein-coupled receptor sphingosine 1-phosphate receptor 5, which plays a key role in NK cell tissue localization $(106,107)$. Both p110 and p110 $\gamma$ are activated for chemotaxis to CXCL12 and CCL3 and mediate NK cell migration to tissue and to the uterus during pregnancy (106). Conversely, NK cells from PTEN-deficient mice have hyperresponsive signaling in response to sphingosine 1-phosphate, leading to an increase in NK cells in peripheral blood as a result of aberrant trafficking to the tissue (79).

Taken together, these studies underscore the importance of PI3K signaling in NK cell development, function, and homeostasis. This importance can be further tested by studying patients with rare mutations in this pathway, particularly when these patients are considered in the context of informative mouse models.

\section{The Requirement for PI3K in NK Cell Lytic Function}

The role of PI3K signaling in immunological synapse formation and function was first tested broadly by using relatively promiscuous inhibitors such as Ly294002 and wortmannin. These studies showed that the broad inhibition of PI3K signaling prevented NK cell cytotoxicity in NK cell lines killing via natural cytotoxicity and in primary cells mediating $\operatorname{ADCC}(86,89$, $108,109)$. While initial studies suggested that PI3K signaling wasn't required for primary NK cell-mediated lysis of K562 targets (109), the pretreatment of IL-2-activated primary NK cells with wortmannin significantly decreases cytotoxicity against 721.221 targets, at least in part by modulating LFA-1 function $(110,111)$. Further studies identified PI3K-Rac1-PAK1-MEK-ERK signaling that is required for polarization and cytotoxicity of human NK cell lines and freshly isolated peripheral blood NK cells (91). Knockdown (KD) of p85 $\alpha$ or AKT prevents lytic granule polarization to the immune synapse and inhibits the activity of Cdc42 (92). In addition, p1108 interacts directly with the SH3 domain of CrkL during NKG2D-mediated NK cell cytotoxicity and controls LFA-1-mediated conjugate formation downstream of NKG2D ligation on human NK cells (86).
Mice deficient for PI3K $\delta$ have impaired NK cell function against tumor targets, including defects in exocytosis $(75,76)$. Similarly, p $85 \alpha$-deficient mice have impaired NK cell cytotoxicity and cytokine production (78). Specific inhibitors of PI3K class I isoforms show that while pan-PI3K inhibition impairs mature human NK cell function, the selective inhibition of PI3K $\alpha,-\beta,-\gamma$, or $-\delta$ does not have a significant effect (112). These results suggest that the genetic loss of PI3K $\delta$ may lead to NK cell developmental defects that are not present when PI3K $\delta$ function is inhibited in mature cells. This is supported further by studies of a mouse expressing catalytically inactive $\mathrm{PI} 3 \mathrm{~K} \delta$, in which signaling is impaired downstream of activating receptors and NK cells fail to mature and are unable to mediate lytic function (77). Overall, however, this is a field that has been complicated by differential findings regarding the requirement for PI3K isoforms in NK cell development, in part due to differences between mouse strains (113).

While human loss-of-function mutations in PI3K1108 (68) and $\mathrm{p} 85 \alpha$ (70) have been reported, they are overwhelmingly rare. Both defects lead to primary immunodeficiency, and NK cell number in the patient reported with $\mathrm{p} 85 \alpha$ deficiency was significantly decreased when compared to healthy ranges (70). What have emerged as a much more common variation are GOF mutations in PIK3CD or PIK3R1. PIK3CD GOF mutations were independently reported in 2014 by Lucas et al. (65) and Angulo et al. (114) and lead to hyperactivation of PI3K $110 \delta$ signaling by interrupting the interaction between PI3K110 $\delta$ and the $\mathrm{p} 85 \alpha$ regulatory subunit, or by constitutive membrane association and activation $(65,114,115)$. This hyperactivation can be detected on a cellular basis as hyperphosphorylation of S6, mTOR, and AKT. Clinically, these mutations can lead to varied phenotypes, and original PIK3CD cohorts were identified by screening patients with recurrent chest infections (114) and herpesviral infections (65), respectively. Patients with activating mutations in PIK3R1 leading to an increased PI3K $\delta$ activity also have primary immunodeficiency $(67,69,116-123)$, and many studies, including large cohort studies, have defined new mutations in PIK3CD leading to activated PI3K delta syndrome (APDS) and expanded the phenotype of disease $(64,66,67,124-131)$. While the clinical features of patients with mutations in PIK3CD and PIK3R1 can be similar, there is evidence that PIK3R1 mutations can also have extra-immune phenotypes (118). To delineate the two where necessary, PIK3CD mutations are referred to as leading to APDS1, whereas mutations in PIK3R1 cause APDS2. Finally, patients have also been identified with PTEN loss-of-function (LOF) mutations that can also lead to features of APDS (71-73).

Immunologically, APDS patients have combined immune deficiency due to impairment in multiple compartments, including B cells, T cells, and more recently described NK cells (63, 65, $114,132)$. B cell function is generally impaired, and an increase in transitional B cell number is a highly conserved phenotype of APDS patients. There are also significant T cell defects in APDS patients, including increased $\mathrm{T}$ cell senescence likely driven by hyperproliferation, at least in some part as a result of an increased mTOR metabolism (65).

A decreased NK cell frequency has been reported in these APDS cohorts $(64-67,69)$; however, a detailed analysis was recently performed that identified multiple facets of deregulated 
NK cell phenotype and function in patients with PI3K GOF mutations (63). This includes a decreased expression of CD16 and an increased expression of CD62L in peripheral blood NK cells, suggesting incomplete terminal maturation. NK cell function is impaired, and the source of this impairment is due to multiple defects in immune synapse formation and function. These include a decreased conjugation with target cells and a decreased phosphorylation of ERK in response to activating signaling. When forming conjugates with susceptible target cells, NK cells from APDS patients have impaired MTOC polarization and actin accumulation at the immunological synapse (63). Collectively, these effects lead to impaired NK cell lytic function mediated against susceptible class I negative, as well as antibodycoated targets. These effects were demonstrated in patients with previously described E525K, E1021K, and N334K mutations, with patients with E525K mutations interestingly having a more severe impairment of NK cell function.

The treatment of patients with the mTOR inhibitor rapamycin led to improved NK cell function and partial restoration of immune synapse formation, suggesting that tonic hyperactivation of the mTOR-AKT pathway is contributing to the functional impairment of NK cells (63). The mechanism of this is currently unclear, however, and the similarity between the effect of PI3K GOF mutations and the previously reported loss-of-function models, namely impaired NK cell cytotoxicity, can be confusing. However, of note, ERK1/2 phosphorylation in response to activation was decreased in NK cells from APDS patients, counter to the expected hyperphosphorylation predicted by an increased AKT phosphorylation (and its responsiveness to rapamycin). The decreased effector function of APDS patient NK cells, combined with a decreased ERK phosphorylation, suggests that long-term hyperactivation of these pathways leads to NK cellular hyporesponsiveness. The partial reversibility of the patients' NK cell function after the initiation of rapamycin treatment suggests that there is tunable signaling in these patient cells that can be responsive to modulation; however, this is also in addition to seemingly hardwired NK cell-developmental defects that were not affected by rapamycin treatment. There also may be differential effects of hyperactive PI3K signaling on the MAPK and AKT pathways. It would be of interest to probe downstream signalosomes with greater detail in APDS patients to determine the localization and activity of key activating and inhibitory mediators such as Vav1, SAP, and SHIP-1. In addition, while not tested in the current study, it would be of interest to test the short-term incubation of patient cells with rapamycin to determine whether NK cell function can similarly be restored by the temporary reversal of mTOR and AKT hyperphosphorylation.

Enhanced signaling through mTOR also leads to enhanced cellular metabolism, and a better understanding of how glycolysis and oxidative phosphorylation shape NK cell function is emerging (133). Consistent with the responsiveness of CD56 $6^{\text {bright }}$ NK cells in response to priming, CD56 $6^{\text {bight }} \mathrm{NK}$ cells become highly metabolically active following cytokine stimulation, which enables their robust production of IFN $\gamma$. The treatment of healthy donor NK cells with rapamycin leads to a decreased production of IFN $\gamma$ and a reduced expression of nutrient receptors such as the transferrin receptor $(103,134)$. mTor-deficient mice have impaired development due to impaired IL-15 responses, and it is likely that metabolic regulation is an important component of PI3K-mTOR-mediated IL-15 signaling and an unexplored component of the NK cell phenotype in APDS patients.

While the standard of care for many APDS patients has been rapamycin, the recent development of selective PI3K $\delta$ inhibitors for the purpose of treating APDS patients has led to the availability of these and preliminary data about their efficacy and modes of action. The treatment of six patients with E525K or E1021K mutations with the selective PI3K $\delta$ inhibitor leniolisib led to reduced phospho-AKT and -S6 in T cells $(135,136)$. While NK cells were not explicitly examined in this study, it will be of interest to determine whether, like rapamycin, specific PI3K $\delta$ inhibition leads to restored function and whether, unlike rapamycin, this treatment also has an effect on NK cell phenotype and maturation.

\section{PTEN, SHIP-1, and SAP Mutations and NK Cell Function}

As APDS occurs as a result of hyperactivation of the PI3Ksignaling pathway, it can be informative to also consider the consequence of LOF mutations in negative regulators of PI3K signaling. Autosomal-dominant mutations in PTEN are a previously described cause of hamartoma tumor syndromes, with a range of clinical effects that include susceptibility to malignancy, mucocutaneous lesions, and macrocephaly (137). Whole-exome sequencing identification of patients with LOF heterozygous mutations in PTEN has identified patients with APDS-like characteristics (71-73). These may include many of the clinical and immunological hallmarks of APDS, including recurrent infections, lymphadenopathy, hepatosplenomegaly, and cytopenias. In addition, APDS PTEN patients had previously described features of PTEN hamartoma tumor syndrome, including macrocephaly and mental retardation. A decreased PTEN protein expression in these patients was accompanied by an increased phospho-S6 and phospho-AKT as predicted $(71,72)$; however, basal PtdIns $(3,4,5) \mathrm{P} 3$ levels were surprisingly unaffected in one patient tested (72). NK cell function in these patients has not been specifically interrogated; however, decreased NK cell numbers were reported in some PTEN patients with immune deficiency (71-73). The variable penetrance of PTEN mutations is not completely understood; however, the capacity for these mutations to phenocopy activating mutations in PIK3CD or PIK3R1 speaks of the importance of modulation of this signaling pathway.

In addition, the expression and functional role of PTEN in healthy donor human NK cells has been specifically interrogated. Overexpression (OE) of PTEN in an NK cell line or primary human or transgenic mouse NK cells leads to loss of NK cell function (74). Mechanistically, this is accompanied by a decreased accumulation of F-actin at the immunological synapse and impaired granule convergence and polarization. PTEN KD in primary mouse or human cells leads to a modest increase in NK cell lytic function, underscoring the role of PTEN as a negative regulator of NK cell cytotoxicity and contrasting the effect of PI3K GOF mutations. Interestingly, unlike mouse models of SHIP-1 and human patients with APDS, in which deregulation 
of this pathway impairs NK cell maturation, there was no reported effect of PTEN OE on NK cell development in the transgenic super-PTEN mouse model. By contrast, SHIP-1-deficient mice have reduced NK cell numbers in the periphery, specifically due to impaired terminal maturation from immature precursors (80). In human NK cells, both SHIP-1 and PTEN have differential expression in mature subsets, with PTEN being highly expressed in CD56 $6^{\text {bright }}$ NK cells (74) and SHIP-1 more highly expressed in the CD56 ${ }^{\mathrm{dim}}$ subset (138). SHIP-1 additionally plays a role in modulating signaling downstream of CD16 as it is recruited to the TCR $\zeta$ chain during ADCC and can negatively regulate cytotoxicity (139).

Finally, the activating receptor $2 \mathrm{~B} 4$ associates with SAP/ $\mathrm{SH} 2 \mathrm{D} 1 \mathrm{~A}$, an SH2-domain-containing adaptor molecule. In addition to other immune defects, patients with X-linked lymphoproliferative disease (XLP) as a result of mutations in SAP have impaired NK cell function (140). The inhibition of PI3K function disrupts the 2B4-SAP interaction, and conversely PI3K function is impaired in patients with SAP mutations (82). As a result, the treatment of NK cells from patients with XLP with PI3K inhibitors does not further affect NK cell-cytotoxic function, whereas in healthy donors, PI3K inhibition impairs NK cell lytic function.

\section{NK Cell Maturation and Homing}

The role of PI3K in cytokine signaling, as well as its role in Rac signaling and actin remodeling, points strongly to a critical role in governing NK cell migration and maturation. In addition, $\mathrm{PI} 3 \mathrm{~K} \gamma$ mediates migration through its association with G-protein-coupled receptors, and p110 $\alpha$ and p110 play a role in lymphocyte chemotaxis and migration. Pan-PI3K inhibition reduces NK cell migration in response to chemokines, and the selective inhibition of $\mathrm{p} 110 \gamma$ or $\mathrm{p} 110 \delta$ shows that both play a role in CXCL12-mediated NK cell migration (106). The deletion of the p1108 isoform in mice leads to a significant decrease in NK cell number in peripheral organs, with distinct phenotypic abnormalities including a decreased expression of Ly49G2, Ly49C/I, and CD11b/CD43 (75). In remaining cells, cytokine secretion, but not production, is impaired, demonstrating a role for $\mathrm{p} 110 \delta$ in both maturation and function. Transgenic mice expressing catalytically inactive p1108 also have reduced numbers of mature NK cells in the periphery, although NK cell progenitors in bone marrow are present at normal frequency (77). As with p1108-deficient mice, catalytically inactive p1108 mice have a decreased frequency of inhibitory Ly49C/I-positive NK cells, indicating impaired terminal maturation or receptor regulation. Discrepancies between isoform-specific knockout mice and catalytically inactive mutants may be due to altered expression of other PI3K subunits following single isoform deletion, including altered $\mathrm{p} 85 \alpha, \mathrm{p} 110 \beta$, and $\mathrm{p} 110 \gamma$ expression in p1108-knockout mice $(141,142)$. PTEN also plays a critical role in NK cell homing, and NK cell-specific PTEN deletion in mice leads to increased NK cell numbers in peripheral blood due to premature egress from the bone marrow and altered response to S1P signals (79).

Whether NK cells from patients with activating PI3K mutations have alterations in NK cell maturation, tissue distribution, homeostasis, or migration is not fully understood. A direct correlation to the effect seen with PTEN deletion in mice is not seen, as abnormal NK cell numbers in peripheral blood of APDS patients have been reported as decreased, not increased $(63-67,69)$. Despite a decreased NK cell number, the ratio of CD56 ${ }^{\text {bright }}$ to CD56 ${ }^{\text {dim }} \mathrm{NK}$ cells is not significantly affected in these patients, suggesting that terminal maturation occurs (63). However, there are receptors that are associated with NK cell development that have significantly altered expression in APDS patient NK cells. These include a decreased expression of CD16 on CD56 ${ }^{\text {dim }}$ NK cells and a decreased expression of CD62L on CD56 ${ }^{\text {bright }}$ NK cells. Altered expression of CD62L could lead to impaired localization in secondary lymphoid tissue, and PTEN knockout mice also have a significantly decreased CD62L expression (79). Notably, NK cells from APDS patients had a significantly decreased expression of CD122, the common gamma chain, and CD127, the IL-7 receptor. Finally, an increased expression of NKG2A on CD56 ${ }^{\text {dim }}$ NK cells from APDS patients is also suggestive of dysregulated maturation. Taken together, however, it is difficult to interpret these selective receptor anomalies with a cohesive defect in a specific aspect of NK cell maturation. Additional studies, including gene expression and, if possible, the study of tissues beyond peripheral blood, are required to definitively isolate defects in NK cell maturation and homing in patients with activating PIK3CD mutations.

\section{What Can Patients with PI3K Mutations Teach Us about NK Cell Function?}

What can we learn about the requirement for, and role of, PI3K signaling in human NK cells from patients with primary immunodeficiency? The discovery of APDS provides us with a robust number of patients to study and underscore the biological complexity of this signaling pathway. While these mutations are termed GOF, and rightly so based upon the hyperphosphorylation of key signaling molecules, they are not represented by an increased NK cell function. This can be partially explained by signs of impaired activation of signaling intermediates such as phospho-ERK and phospho-JNK (63), suggesting that NK cell hyporesponsiveness may result from constitutive overactivation of the pathway. This apparent hyporesponsiveness is also in contrast to studies of human cells in which PTEN levels have been transiently manipulated, with KD of PTEN leading to an increased NK cell function in this system, as would be predicted by the loss of inhibition of the PI3K-signaling pathway (Figure 1) (74). The mechanism of hyporesponsiveness in APDS patient NK cells is unclear, but the restoration of function following rapamycin treatment suggests that this may be a reversible condition. Currently, however, we do not know whether the effect of rapamycin is on long-term NK cell development or on survival, or whether short-term rapamycin treatment would lead to similar regained function. Treatment of patients with rapamycin may lead to the replenishment over time of NK cell subsets that have developed with modulated IL-15-mTOR signaling, leading to the restoration of functional capacity. Given the particular susceptibility of these patients to herpesviral infection (including Epstein-Barr virus, cytomegalovirus, and varicella zoster), it is likely that their NK cell dysfunction contributes to this clinical phenotype. 


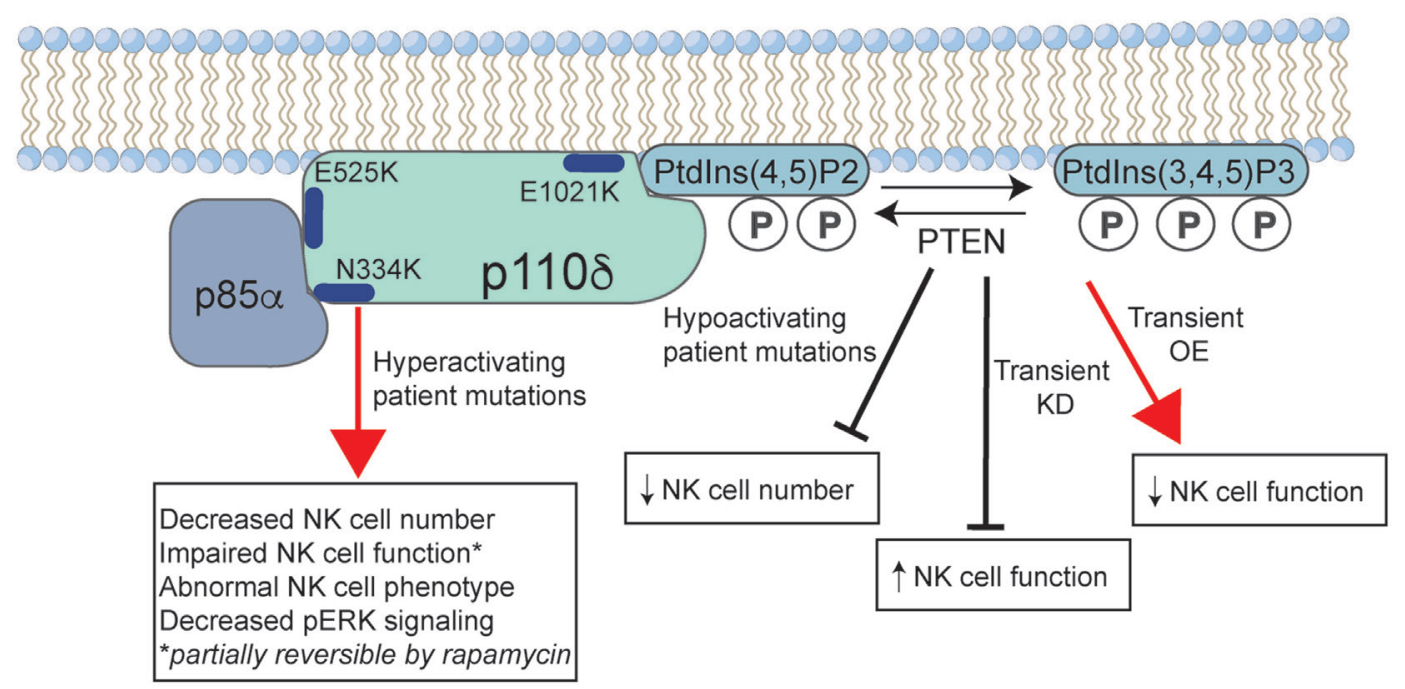

FIGURE 1 | The effect of activated PI3K delta syndrome (APDS)-causing mutations on human natural killer (NK) cell function. Common mutations in p1108 that lead to disease are shown, including those that lead to loss of negative regulation by the p85 $\alpha$-regulatory subunit (E525K, N334K), and the E1021K mutation that leads to constitutive membrane association. Phosphoinositide-3-kinase (PI3K) p1108 catalyzes the conversion of Ptdlns( 3,4$) P 2$ to Ptdlns $(3,4,5) \mathrm{P} 3$ at the cell membrane, a reaction that is negatively regulated by phosphatase and tensin homolog (PTEN). Gain-of-function mutations in PI3K lead to a decreased NK cell number and aberrant phenotype. While less well described, patients with loss-of-function mutations in PTEN may have an APDS phenotype that is accompanied by a decreased NK cell number. Studies of short-term KD or OE of PTEN in human NK cells lead to increased and decreased NK cell functions, respectively. P, phosphate; KD, knockdown; OE, overexpression.

It is also important to consider the overall immune environment in these patients. Deregulation of the B and T cell subsets may additionally affect the generation or homeostasis of NK cell subsets, through direct or indirect mechanisms. It will be of value to study the NK cells of these patients more closely to better determine the molecular basis of dysfunction. In addition, a mouse model of APDS would enable the further dissection of the effect of activated PI3K on NK cell development, migration, and cytotoxicity. Better understanding of the effect of these mutations specifically on NK cells will be important for better understanding and implementing the next generation of therapies, including targeted small molecule inhibitors. As always in the case of primary immunodeficiency, these patients also provide us the rare opportunity to better understand the requirements for human immunity through the study of a uniquely human model.

\section{REFERENCES}

1. Bjorkstrom NK, Ljunggren HG, Michaelsson J. Emerging insights into natural killer cells in human peripheral tissues. Nat Rev Immunol (2016) 16(5):310-20. doi:10.1038/nri.2016.34

2. Freud AG, Becknell B, Roychowdhury S, Mao HC, Ferketich AK, Nuovo GJ, et al. A human CD34(+) subset resides in lymph nodes and differentiates into CD56 ${ }^{\text {bright }}$ natural killer cells. Immunity (2005) 22(3): 295-304. doi:10.1016/j.immuni.2005.01.013

3. Freud AG, Caligiuri MA. Human natural killer cell development. Immunol Rev (2006) 214:56-72. doi:10.1111/j.1600-065X.2006.00451.x

4. Yu J, Freud AG, Caligiuri MA. Location and cellular stages of natural killer cell development. Trends Immunol (2013) 34(12):573-82. doi:10.1016/ j.it.2013.07.005

\section{AUTHOR CONTRIBUTIONS}

All the work was performed by EM.

\section{ACKNOWLEDGMENTS}

I would like to thank all the patients and their families who participated in scientific research and colleagues within the primary immunodeficiency community for their engaging and meaningful collaboration.

\section{FUNDING}

This work was supported by an American Society of Hematology Junior Scholar Award to EM.

5. Michel T, Poli A, Cuapio A, Briquemont B, Iserentant G, Ollert M, et al. Human CD56 ${ }^{\text {bright }}$ NK cells: an update. J Immunol (2016) 196(7):2923-31. doi:10.4049/jimmunol.1502570

6. Ferlazzo G, Thomas D, Lin SL, Goodman K, Morandi B, Muller WA, et al. The abundant NK cells in human secondary lymphoid tissues require activation to express killer cell Ig-like receptors and become cytolytic. J Immunol (2004) 172(3):1455-62. doi:10.4049/jimmunol.172.3.1455

7. Nielsen N, Odum N, Urso B, Lanier LL, Spee P. Cytotoxicity of CD56 (bright) NK cells towards autologous activated $\mathrm{CD}^{+} \mathrm{T}$ cells is mediated through NKG2D, LFA-1 and TRAIL and dampened via CD94/NKG2A. PLoS One (2012) 7(2):e31959. doi:10.1371/journal.pone.0031959

8. Ellis TM, Fisher RI. Functional heterogeneity of Leu $19^{\text {"bright" }}+$ and Leu $19^{\text {"dim" }}+$ lymphokine-activated killer cells. J Immunol (1989) 142(8): 2949-54. 
9. Nagler A, Lanier LL, Cwirla S, Phillips JH. Comparative studies of human FcRIII-positive and negative natural killer cells. J Immunol (1989) 143(10): 3183-91.

10. Wagner JA, Rosario M, Romee R, Berrien-Elliott MM, Schneider SE, Leong JW, et al. CD56 ${ }^{\text {bright }} \mathrm{NK}$ cells exhibit potent antitumor responses following IL-15 priming. J Clin Invest (2017) 127(11):4042-58. doi:10.1172/ JCI90387

11. Bjorkstrom NK, Riese P, Heuts F, Andersson S, Fauriat C, Ivarsson MA, et al. Expression patterns of NKG2A, KIR, and CD57 define a process of CD56 ${ }^{\mathrm{dim}}$ NK-cell differentiation uncoupled from NK-cell education. Blood (2010) 116(19):3853-64. doi:10.1182/blood-2010-04-281675

12. Guma M, Budt M, Saez A, Brckalo T, Hengel H, Angulo A, et al. Expansion of $\mathrm{CD} 94 / \mathrm{NKG}_{2} \mathrm{C}^{+} \mathrm{NK}$ cells in response to human cytomegalovirusinfected fibroblasts. Blood (2006) 107(9):3624-31. doi:10.1182/blood-2005$09-3682$

13. Lopez-Verges S, Milush JM, Pandey S, York VA, Arakawa-Hoyt J, Pircher H, et al. CD57 defines a functionally distinct population of mature NK cells in the human CD56 ${ }^{\mathrm{dim}} \mathrm{CD} 16+$ NK-cell subset. Blood (2010) 116(19):3865-74. doi:10.1182/blood-2010-04-282301

14. Lopez-Verges S, Milush JM, Schwartz BS, Pando MJ, Jarjoura J, York VA, et al. Expansion of a unique CD57(+)NKG2Chi natural killer cell subset during acute human cytomegalovirus infection. Proc Natl Acad Sci U S A (2011) 108(36):14725-32. doi:10.1073/pnas.1110900108

15. Beziat V, Liu LL, Malmberg JA, Ivarsson MA, Sohlberg E, Bjorklund AT, et al. NK cell responses to cytomegalovirus infection lead to stable imprints in the human KIR repertoire and involve activating KIRs. Blood (2013) 121(14):2678-88. doi:10.1182/blood-2012-10-459545

16. Schlums H, Cichocki F, Tesi B, Theorell J, Beziat V, Holmes TD, et al. Cytomegalovirus infection drives adaptive epigenetic diversification of NK cells with altered signaling and effector function. Immunity (2015) 42(3): 443-56. doi:10.1016/j.immuni.2015.02.008

17. Lee J, Zhang T, Hwang I, Kim A, Nitschke L, Kim M, et al. Epigenetic modification and antibody-dependent expansion of memory-like NK cells in human cytomegalovirus-infected individuals. Immunity (2015) 42(3): 431-42. doi:10.1016/j.immuni.2015.02.013

18. Monks CR, Freiberg BA, Kupfer H, Sciaky N, Kupfer A. Three-dimensional segregation of supramolecular activation clusters in T cells. Nature (1998) 395(6697):82-6. doi:10.1038/25764

19. Grakoui A, Bromley SK, Sumen C, Davis MM, Shaw AS, Allen PM, et al. The immunological synapse: a molecular machine controlling $\mathrm{T}$ cell activation. Science (1999) 285(5425):221-7. doi:10.1126/science.285.5425.221

20. Davis DM, Chiu I, Fassett M, Cohen GB, Mandelboim O, Strominger JL. The human natural killer cell immune synapse. Proc Natl Acad Sci U S A (1999) 96(26):15062-7. doi:10.1073/pnas.96.26.15062

21. Wulfing C, Purtic B, Klem J, Schatzle JD. Stepwise cytoskeletal polarization as a series of checkpoints in innate but not adaptive cytolytic killing. Proc Natl Acad Sci U S A (2003) 100(13):7767-72. doi:10.1073/pnas.1336920100

22. Mace EM, Dongre P, Hsu HT, Sinha P, James AM, Mann SS, et al. Cell biological steps and checkpoints in accessing NK cell cytotoxicity. Immunol Cell Biol (2014) 92(3):245-55. doi:10.1038/icb.2013.96

23. Yokoyama WM, Kim S. Licensing of natural killer cells by self-major histocompatibility complex class I. Immunol Rev (2006) 214:143-54. doi:10.1111/j.1600-065X.2006.00458.x

24. Kim S, Poursine-Laurent J, Truscott SM, Lybarger L, Song YJ, Yang L, et al. Licensing of natural killer cells by host major histocompatibility complex class I molecules. Nature (2005) 436(7051):709-13. doi:10.1038/ nature 03847

25. Fernandez NC, Treiner E, Vance RE, Jamieson AM, Lemieux S, Raulet DH. A subset of natural killer cells achieves self-tolerance without expressing inhibitory receptors specific for self-MHC molecules. Blood (2005) 105(11): 4416-23. doi:10.1182/blood-2004-08-3156

26. Elliott JM, Wahle JA, Yokoyama WM. MHC class I-deficient natural killer cells acquire a licensed phenotype after transfer into an MHC class I-sufficient environment. J Exp Med (2010) 207(10):2073-9. doi:10.1084/ jem.20100986

27. Joncker NT, Shifrin N, Delebecque F, Raulet DH. Mature natural killer cells reset their responsiveness when exposed to an altered MHC environment. J Exp Med (2010) 207(10):2065-72. doi:10.1084/jem.20100570
28. Chalifour A, Scarpellino L, Back J, Brodin P, Devevre E, Gros F, et al. A Role for cis interaction between the inhibitory Ly49A receptor and MHC class I for natural killer cell education. Immunity (2009) 30(3):337-47. doi:10.1016/j.immuni.2008.12.019

29. Brodin P, Lakshmikanth T, Johansson S, Karre K, Hoglund P. The strength of inhibitory input during education quantitatively tunes the functional responsiveness of individual natural killer cells. Blood (2009) 113(11): 2434-41. doi:10.1182/blood-2008-05-156836

30. Beuneu H, Deguine J, Breart B, Mandelboim O, Di Santo JP, Bousso P. Dynamic behavior of NK cells during activation in lymph nodes. Blood (2009) 114(15):3227-34. doi:10.1182/blood-2009-06-228759

31. Bajenoff M, Breart B, Huang AY, Qi H, Cazareth J, Braud VM, et al. Natural killer cell behavior in lymph nodes revealed by static and real-time imaging. J Exp Med (2006) 203(3):619-31. doi:10.1084/jem.20051474

32. Garrod KR, Wei SH, Parker I, Cahalan MD. Natural killer cells actively patrol peripheral lymph nodes forming stable conjugates to eliminate MHCmismatched targets. Proc Natl Acad Sci U S A (2007) 104(29):12081-6. doi:10.1073/pnas.0702867104

33. Mace EM, Gunesch JT, Dixon A, Orange JS. Human NK cell development requires CD56-mediated motility and formation of the developmental synapse. Nat Commun (2016) 7:12171. doi:10.1038/ncomms12171

34. Lee BJ, Mace EM. Acquisition of cell migration defines NK cell differentiation from hematopoietic stem cell precursors. Mol Biol Cell (2017) 28(25): 3573-81. doi:10.1091/mbc.E17-08-0508

35. Khorshidi MA, Vanherberghen B, Kowalewski JM, Garrod KR, Lindstrom S, Andersson-Svahn H, et al. Analysis of transient migration behavior of natural killer cells imaged in situ and in vitro. Integr Biol (Camb) (2011) 3(7): 770-8. doi:10.1039/clib00007a

36. Vanherberghen B, Olofsson PE, Forslund E, Sternberg-Simon M, Khorshidi MA, Pacouret S, et al. Classification of human natural killer cells based on migration behavior and cytotoxic response. Blood (2013) 121(8):1326-34. doi:10.1182/blood-2012-06-439851

37. Bhat R, Watzl C. Serial killing of tumor cells by human natural killer cells-enhancement by therapeutic antibodies. PLoS One (2007) 2(3):e326. doi:10.1371/journal.pone.0000326

38. Choi PJ, Mitchison TJ. Imaging burst kinetics and spatial coordination during serial killing by single natural killer cells. Proc Natl Acad Sci U S A (2013) 110(16):6488-93. doi:10.1073/pnas.1221312110

39. Forslund E, Sohlberg E, Enqvist M, Olofsson PE, Malmberg KJ, Onfelt B. Microchip-based single-cell imaging reveals that $\mathrm{CD} 56{ }^{\mathrm{dim}} \mathrm{CD} 57-\mathrm{KIR}-$ $\mathrm{NKG}_{2} \mathrm{~A}^{+} \mathrm{NK}$ cells have more dynamic migration associated with increased target cell conjugation and probability of killing compared to CD56 ${ }^{\mathrm{dim}} \mathrm{CD} 57-$ KIR-NKG2A- NK cells. J Immunol (2015) 195(7):3374-81. doi:10.4049/ jimmunol.1500171

40. Olofsson PE, Forslund E, Vanherberghen B, Chechet K, Mickelin O, Ahlin AR, et al. Distinct migration and contact dynamics of resting and IL-2-activated human natural killer cells. Front Immunol (2014) 5:80. doi:10.3389/fimmu. 2014.00080

41. Orange JS, Ramesh N, Remold-O’Donnell E, Sasahara Y, Koopman L, Byrne M, et al. Wiskott-Aldrich syndrome protein is required for NK cell cytotoxicity and colocalizes with actin to NK cell-activating immunologic synapses. Proc Natl Acad Sci U S A (2002) 99(17):11351-6. doi:10.1073/pnas. 162376099

42. Orange JS, Roy-Ghanta S, Mace EM, Maru S, Rak GD, Sanborn KB, et al. IL-2 induces a WAVE2-dependent pathway for actin reorganization that enables WASp-independent human NK cell function. J Clin Invest (2011) 121(4):1535-48. doi:10.1172/JCI44862

43. Sanborn KB, Rak GD, Maru SY, Demers K, Difeo A, Martignetti JA, et al. Myosin IIA associates with NK cell lytic granules to enable their interaction with F-actin and function at the immunological synapse. J Immunol (2009) 182(11):6969-84. doi:10.4049/jimmunol.0804337

44. Sanborn KB, Mace EM, Rak GD, Difeo A, Martignetti JA, Pecci A, et al. Phosphorylation of the myosin IIA tailpiece regulates single myosin IIA molecule association with lytic granules to promote NK-cell cytotoxicity. Blood (2011) 118(22):5862-71. doi:10.1182/blood-2011-03-344846

45. Mizesko MC, Banerjee PP, Monaco-Shawver L, Mace EM, Bernal WE, Sawalle-Belohradsky J, et al. Defective actin accumulation impairs human natural killer cell function in patients with dedicator of cytokinesis 8 
deficiency. J Allergy Clin Immunol (2013) 131(3):840-8. doi:10.1016/j.jaci. 2012.12.1568

46. Mace EM, Orange JS. Lytic immune synapse function requires filamentous actin deconstruction by Coronin 1A. Proc Natl Acad Sci U S A (2014) 111(18):6708-13. doi:10.1073/pnas.1314975111

47. Mace EM, Orange JS. Genetic causes of human NK cell deficiency and their effect on NK cell subsets. Front Immunol (2016) 7:545. doi:10.3389/ fimmu.2016.00545

48. Voss M, Bryceson YT. Natural killer cell biology illuminated by primary immunodeficiency syndromes in humans. Clin Immunol (2017) 177:29-42. doi:10.1016/j.clim.2015.11.004

49. Hughes CR, Guasti L, Meimaridou E, Chuang CH, Schimenti JC, King PJ, et al. MCM4 mutation causes adrenal failure, short stature, and natural killer cell deficiency in humans. J Clin Invest (2012) 122(3):814-20. doi:10.1172/ JCI60224

50. Gineau L, Cognet C, Kara N, Lach FP, Dunne J, Veturi U, et al. Partial MCM4 deficiency in patients with growth retardation, adrenal insufficiency, and natural killer cell deficiency. J Clin Invest (2012) 122(3):821-32. doi:10.1172/ JCI61014

51. Cottineau J, Kottemann MC, Lach FP, Kang YH, Vely F, Deenick EK, et al. Inherited GINS1 deficiency underlies growth retardation along with neutropenia and NK cell deficiency. J Clin Invest (2017) 127(5):1991-2006. doi:10.1172/JCI90727

52. Mace EM, Bigley V, Gunesch JT, Chinn IK, Angelo LS, Care MA, et al. Biallelic mutations in IRF8 impair human NK cell maturation and function. J Clin Invest (2017) 127(1):306-20. doi:10.1172/JCI86276

53. Hanna S, Beziat V, Jouanguy E, Casanova JL, Etzioni A. A homozygous mutation of RTEL1 in a child presenting with an apparently isolated natural killer cell deficiency. J Allergy Clin Immunol (2015) 136(4):1113-4. doi:10.1016/j.jaci.2015.04.021

54. Etzioni A, Eidenschenk C, Katz R, Beck R, Casanova JL, Pollack S. Fatal varicella associated with selective natural killer cell deficiency. J Pediatr (2005) 146(3):423-5. doi:10.1016/j.jpeds.2004.11.022

55. Spinner MA, Sanchez LA, Hsu AP, Shaw PA, Zerbe CS, Calvo KR, et al. GATA2 deficiency: a protean disorder of hematopoiesis, lymphatics, and immunity. Blood (2014) 123(6):809-21. doi:10.1182/blood-2013-07515528

56. Mace EM, Hsu AP, Monaco-Shawver L, Makedonas G, Rosen JB, Dropulic L, et al. Mutations in GATA2 cause human NK cell deficiency with specific loss of the CD56(bright) subset. Blood (2013) 121(14):2669-77. doi:10.1182/ blood-2012-09-453969

57. Schlums H, Jung M, Han H, Theorell J, Bigley V, Chiang SC, et al. Adaptive NK cells can persist in patients with GATA2 mutation depleted of stem and progenitor cells. Blood (2017) 129(14):1927-39. doi:10.1182/blood2016-08-734236

58. Maciejewski-Duval A, Meuris F, Bignon A, Aknin ML, Balabanian K, Faivre L, et al. Altered chemotactic response to CXCL12 in patients carrying GATA2 mutations. J Leukoc Biol (2016) 99(6):1065-76. doi:10.1189/ jlb.5MA0815-388R

59. Noguchi M, Yi H, Rosenblatt HM, Filipovich AH, Adelstein S, Modi WS, et al. Interleukin-2 receptor gamma chain mutation results in X-linked severe combined immunodeficiency in humans. Cell (1993) 73(1):147-57. doi:10.1016/0092-8674(93)90167-O

60. Roberts JL, Lengi A, Brown SM, Chen M, Zhou YJ, O'Shea JJ, et al. Janus kinase 3 (JAK3) deficiency: clinical, immunologic, and molecular analyses of 10 patients and outcomes of stem cell transplantation. Blood (2004) 103(6):2009-18. doi:10.1182/blood-2003-06-2104

61. Vargas-Hernández A, Mace EM, Zimmerman O, Zerbe CS, Freeman AF, Rosenzweig $S$, et al. Ruxolitinib partially reverses functional natural killer cell deficiency in patients with signal transducer and activator of transcription 1 (STAT1) gain-of-function mutations. J Allergy Clin Immunol (2017):31647. doi:10.1016/j.jaci.2017.08.040

62. Zhu S, Phatarpekar PV, Denman CJ, Senyukov VV, Somanchi SS, NguyenJackson HT, et al. Transcription of the activating receptor NKG2D in natural killer cells is regulated by STAT3 tyrosine phosphorylation. Blood (2014) 124(3):403-11. doi:10.1182/blood-2013-05-499707

63. Ruiz-García R, Vargas-Hernández A, Chinn IK, Angelo LS, Cao TN, CobanAkdemir Z, et al. Mutations in PI3K1108 cause impaired natural killer cell function partially rescued by rapamycin treatment. J Allergy Clin Immunol (2018). doi:10.1016/j.jaci.2017.11.042

64. Coulter TI, Chandra A, Bacon CM, Babar J, Curtis J, Screaton N, et al. Clinical spectrum and features of activated phosphoinositide 3-kinase delta syndrome: a large patient cohort study. J Allergy Clin Immunol (2017) 139(2):597-606.e4. doi:10.1016/j.jaci.2016.06.021

65. Lucas CL, Kuehn HS, Zhao F, Niemela JE, Deenick EK, Palendira U, et al. Dominant-activating germline mutations in the gene encoding the $\mathrm{PI}(3) \mathrm{K}$ catalytic subunit p110delta result in $\mathrm{T}$ cell senescence and human immunodeficiency. Nat Immunol (2014) 15(1):88-97. doi:10.1038/ni.2771

66. Kracker S, Curtis J, Ibrahim MA, Sediva A, Salisbury J, Campr V, et al. Occurrence of B-cell lymphomas in patients with activated phosphoinositide 3-kinase delta syndrome. J Allergy Clin Immunol (2014) 134(1):233-6. doi:10.1016/j.jaci.2014.02.020

67. Wentink M, Dalm V, Lankester AC, van Schouwenburg PA, Scholvinck L, Kalina T, et al. Genetic defects in PI3Kdelta affect B-cell differentiation and maturation leading to hypogammaglobulineamia and recurrent infections. Clin Immunol (2017) 176:77-86. doi:10.1016/j.clim.2017.01.004

68. Zhang KJ, Husami A, Marsh R, Jordan MB. Identification of a phosphoinositide 3-kinase (PI-3K) p1108 (PIK3CD) deficient individual. J Clin Immunol (2013) 33:673-4.

69. Deau MC, Heurtier L, Frange P, Suarez F, Bole-Feysot C, Nitschke P, et al. A human immunodeficiency caused by mutations in the PIK3R1 gene. J Clin Invest (2014) 124(9):3923-8. doi:10.1172/JCI75746

70. Conley ME, Dobbs AK, Quintana AM, Bosompem A, Wang YD, CoustanSmith E, et al. Agammaglobulinemia and absent B lineage cells in a patient lacking the p85alpha subunit of PI3K. J Exp Med (2012) 209(3):463-70. doi:10.1084/jem.20112533

71. Tsujita Y, Mitsui-Sekinaka K, Imai K, Yeh TW, Mitsuiki N, Asano T, et al. Phosphatase and tensin homolog (PTEN) mutation can cause activated phosphatidylinositol 3-kinase delta syndrome-like immunodeficiency. J Allergy Clin Immunol (2016) 138(6):1672-80.e10. doi:10.1016/j.jaci.2016. 03.055

72. Browning MJ, Chandra A, Carbonaro V, Okkenhaug K, Barwell J. Cowden's syndrome with immunodeficiency. J Med Genet (2015) 52(12):856-9. doi:10.1136/jmedgenet-2015-103266

73. Driessen GJ, IJspeert H, Wentink M, Yntema HG, van Hagen PM, van Strien A, et al. Increased PI3K/Akt activity and deregulated humoral immune response in human PTEN deficiency. J Allergy Clin Immunol (2016) 138(6):1744-7.e5. doi:10.1016/j.jaci.2016.07.010

74. Briercheck EL, Trotta R, Chen L, Hartlage AS, Cole JP, Cole TD, et al. PTEN is a negative regulator of NK cell cytolytic function. J Immunol (2015) 194(4):1832-40. doi:10.4049/jimmunol.1401224

75. Kim N, Saudemont A, Webb L, Camps M, Ruckle T, Hirsch E, et al. The p110delta catalytic isoform of PI3K is a key player in NK-cell development and cytokine secretion. Blood (2007) 110(9):3202-8. doi:10.1182/ blood-2007-02-075366

76. Zebedin E, Simma O, Schuster C, Putz EM, Fajmann S, Warsch W, et al. Leukemic challenge unmasks a requirement for PI3Kdelta in NK cellmediated tumor surveillance. Blood (2008) 112(12):4655-64. doi:10.1182/ blood-2008-02-139105

77. Guo H, Samarakoon A, Vanhaesebroeck B, Malarkannan S. The p110 delta of PI3K plays a critical role in NK cell terminal maturation and cytokine/ chemokine generation. J Exp Med (2008) 205(10):2419-35. doi:10.1084/ jem. 20072327

78. Awasthi A, Samarakoon A, Dai X, Wen R, Wang D, Malarkannan S. Deletion of PI3K-p85alpha gene impairs lineage commitment, terminal maturation, cytokine generation and cytotoxicity of NK cells. Genes Immun (2008) 9(6):522-35. doi:10.1038/gene.2008.45

79. Leong JW, Schneider SE, Sullivan RP, Parikh BA, Anthony BA, Singh A, et al. PTEN regulates natural killer cell trafficking in vivo. Proc Natl Acad Sci U S A (2015) 112(7):E700-9. doi:10.1073/pnas.1413886112

80. Banh C, Miah SM, Kerr WG, Brossay L. Mouse natural killer cell development and maturation are differentially regulated by SHIP-1. Blood (2012) 120(23):4583-90. doi:10.1182/blood-2012-04-425009

81. Vanhaesebroeck B, Whitehead MA, Pineiro R. Molecules in medicine mini-review: isoforms of PI3K in biology and disease. J Mol Med (Berl) (2016) 94(1):5-11. doi:10.1007/s00109-015-1352-5 
82. Aoukaty A, Tan R. Association of the X-linked lymphoproliferative disease gene product $\mathrm{SAP} / \mathrm{SH} 2 \mathrm{D} 1 \mathrm{~A}$ with $2 \mathrm{~B} 4$, a natural killer cell-activating molecule, is dependent on phosphoinositide 3-kinase. J Biol Chem (2002) 277(15): 13331-7. doi:10.1074/jbc.M112029200

83. Marti F, Xu CW, Selvakumar A, Brent R, Dupont B, King PD. LCKphosphorylated human killer cell-inhibitory receptors recruit and activate phosphatidylinositol 3-kinase. Proc Natl Acad Sci U S A (1998) 95(20): 11810-5. doi:10.1073/pnas.95.20.11810

84. Eissmann P, Beauchamp L, Wooters J, Tilton JC, Long EO, Watzl C. Molecular basis for positive and negative signaling by the natural killer cell receptor 2B4(CD244). Blood(2005) 105(12):4722-9. doi:10.1182/blood-2004-09-3796

85. Upshaw JL, Arneson LN, Schoon RA, Dick CJ, Billadeau DD, Leibson PJ. NKG2D-mediated signaling requires a DAP10-bound Grb2-Vav1 intermediate and phosphatidylinositol-3-kinase in human natural killer cells. Nat Immunol (2006) 7(5):524-32. doi:10.1038/ni1325

86. Segovis CM, Schoon RA, Dick CJ, Nacusi LP, Leibson PJ, Billadeau DD. PI3K links NKG2D signaling to a CrkL pathway involved in natural killer cell adhesion, polarity, and granule secretion. J Immunol (2009) 182(11): 6933-42. doi:10.4049/jimmunol.0803840

87. Wu J, Song Y, Bakker AB, Bauer S, Spies T, Lanier LL, et al. An activating immunoreceptor complex formed by NKG2D and DAP10. Science (1999) 285(5428):730-2. doi:10.1126/science.285.5428.730

88. Billadeau DD, Upshaw JL, Schoon RA, Dick CJ, Leibson PJ. NKG2DDAP10 triggers human NK cell-mediated killing via a Syk-independent regulatory pathway. Nat Immunol (2003) 4(6):557-64. doi:10.1038/ni929

89. Kanakaraj P, Duckworth B, Azzoni L, Kamoun M, Cantley LC, Perussia B. Phosphatidylinositol-3 kinase activation induced upon Fc gamma RIIIAligand interaction.J ExpMed(1994) 179(2):551-8. doi:10.1084/jem.179.2.551

90. Galandrini R, Micucci F, Tassi I, Cifone MG, Cinque B, Piccoli M, et al. Arf6: a new player in FcgammaRIIIA lymphocyte-mediated cytotoxicity. Blood (2005) 106(2):577-83. doi:10.1182/blood-2004-10-4100

91. Jiang K, Zhong B, Gilvary DL, Corliss BC, Hong-Geller E, Wei S, et al. Pivotal role of phosphoinositide-3 kinase in regulation of cytotoxicity in natural killer cells. Nat Immunol (2000) 1(5):419-25. doi:10.1038/80859

92. Carlin LM, Evans R, Milewicz H, Fernandes L, Matthews DR, Perani M, et al. A targeted siRNA screen identifies regulators of Cdc42 activity at the natural killer cell immunological synapse. Sci Signal (2011) 4(201):ra81. doi:10.1126/scisignal.2001729

93. Ma A, Koka R, Burkett P. Diverse functions of IL-2, IL-15, and IL-7 in lymphoid homeostasis. Annu Rev Immunol (2006) 24:657-79. doi:10.1146/ annurev.immunol.24.021605.090727

94. Ali AK, Nandagopal N, Lee SH. IL-15-PI3K-AKT-mTOR: a critical pathway in the life journey of natural killer cells. Front Immunol (2015) 6:355. doi:10.3389/fimmu.2015.00355

95. Yang M, Li D, Chang Z, Yang Z, Tian Z, Dong Z. PDK1 orchestrates early NK cell development through induction of E4BP4 expression and maintenance of IL-15 responsiveness. J Exp Med (2015) 212(2):253-65. doi:10.1084/ jem.20141703

96. Fehniger TA, Cai SF, Cao X, Bredemeyer AJ, Presti RM, French AR, et al. Acquisition of murine NK cell cytotoxicity requires the translation of a pre-existing pool of granzyme B and perforin mRNAs. Immunity (2007) 26(6):798-811. doi:10.1016/j.immuni.2007.04.010

97. Lucas M, Schachterle W, Oberle K, Aichele P, Diefenbach A. Dendritic cells prime natural killer cells by trans-presenting interleukin 15. Immunity (2007) 26(4):503-17. doi:10.1016/j.immuni.2007.03.006

98. Chaix J, Tessmer MS, Hoebe K, Fuseri N, Ryffel B, Dalod M, et al. Cutting edge: priming of NK cells by IL-18. J Immunol (2008) 181(3):1627-31. doi:10.4049/ jimmunol.181.3.1627

99. Romee R, Schneider SE, Leong JW, Chase JM, Keppel CR, Sullivan RP, et al. Cytokine activation induces human memory-like NK cells. Blood (2012) 120(24):4751-60. doi:10.1182/blood-2012-04-419283

100. Cooper MA, Elliott JM, Keyel PA, Yang L, Carrero JA, Yokoyama WM. Cytokine-induced memory-like natural killer cells. Proc Natl Acad Sci U S A (2009) 106(6):1915-9. doi:10.1073/pnas.0813192106

101. Romee R, Rosario M, Berrien-Elliott MM, Wagner JA, Jewell BA, Schappe T, et al. Cytokine-induced memory-like natural killer cells exhibit enhanced responses against myeloid leukemia. Sci Transl Med (2016) 8(357):357ra123. doi:10.1126/scitranslmed.aaf2341
102. Romee R, Leong JW, Fehniger TA. Utilizing cytokines to function-enable human NK cells for the immunotherapy of cancer. Scientifica (Cairo) (2014) 2014:205796. doi:10.1155/2014/205796

103. Nandagopal N, Ali AK, Komal AK, Lee SH. The critical role of IL-15PI3K-mTOR pathway in natural killer cell effector functions. Front Immunol (2014) 5:187. doi:10.3389/fimmu.2014.00187

104. Fortenbery NR, Paraiso KH, Taniguchi M, Brooks C, Ibrahim L, Kerr WG. SHIP influences signals from CD48 and MHC class I ligands that regulate NK cell homeostasis, effector function, and repertoire formation. J Immunol (2010) 184(9):5065-74. doi:10.4049/jimmunol.0901862

105. al-Aoukaty A, Rolstad B, Maghazachi AA. Recruitment of pleckstrin and phosphoinositide 3-kinase gamma into the cell membranes, and their association with $\mathrm{G}$ beta gamma after activation of NK cells with chemokines. J Immunol (1999) 162(6):3249-55.

106. Saudemont A, Garcon F, Yadi H, Roche-Molina M, Kim N, SegondsPichon A, et al. p110gamma and p110delta isoforms of phosphoinositide 3-kinase differentially regulate natural killer cell migration in health and disease. Proc Natl Acad Sci U S A (2009) 106(14):5795-800. doi:10.1073/pnas. 0808594106

107. Jenne CN, Enders A, Rivera R, Watson SR, Bankovich AJ, Pereira JP, et al. T-bet-dependent S1P5 expression in NK cells promotes egress from lymph nodes and bone marrow. J Exp Med (2009) 206(11):2469-81. doi:10.1084/ jem. 20090525

108. Zhong B, Liu JH, Gilvary DL, Jiang K, Kasuga M, Ritchey CA, et al. Functional role of phosphatidylinositol 3-kinase in direct tumor lysis by human natural killer cells. Immunobiology (2002) 205(1):74-94. doi:10.1078/ 0171-2985-00112

109. Bonnema JD, Rivlin KA, Ting AT, Schoon RA, Abraham RT, Leibson PJ. Cytokine-enhanced NK cell-mediated cytotoxicity. Positive modulatory effects of IL-2 and IL-12 on stimulus-dependent granule exocytosis. J Immunol (1994) 152(5):2098-104.

110. Barber DF, Long EO. Coexpression of CD58 or CD48 with intercellular adhesion molecule 1 on target cells enhances adhesion of resting NK cells. J Immunol (2003) 170(1):294-9. doi:10.4049/jimmunol.170.1.294

111. Barber DF, Faure M, Long EO. LFA-1 contributes an early signal for NK cell cytotoxicity. J Immunol (2004) 173(6):3653-9. doi:10.4049/jimmunol.173. 6.3653

112. Yea SS, So L, Mallya S, Lee J, Rajasekaran K, Malarkannan S, et al. Effects of novel isoform-selective phosphoinositide 3-kinase inhibitors on natural killer cell function. PLoS One (2014) 9(6):e99486. doi:10.1371/journal. pone.0099486

113. Kerr WG, Colucci F. Inositol phospholipid signaling and the biology of natural killer cells. J Innate Immun (2011) 3(3):249-57. doi:10.1159/000323920

114. Angulo I, Vadas O, Garcon F, Banham-Hall E, Plagnol V, Leahy TR, et al. Phosphoinositide 3-kinase delta gene mutation predisposes to respiratory infection and airway damage. Science (2013) 342(6160):866-71. doi:10.1126/ science. 1243292

115. Dornan GL, Siempelkamp BD, Jenkins ML, Vadas O, Lucas CL, Burke JE. Conformational disruption of PI3Kdelta regulation by immunodeficiency mutations in PIK3CD and PIK3R1. Proc Natl Acad Sci U S A (2017) 114(8): 1982-7. doi:10.1073/pnas.1617244114

116. Martinez-Saavedra MT, Garcia-Gomez S, Dominguez Acosta A, Mendoza Quintana JJ, Paez JP, Garcia-Reino EJ, et al. Gain-of-function mutation in PIK3R1 in a patient with a narrow clinical phenotype of respiratory infections. Clin Immunol (2016) 173:117-20. doi:10.1016/j.clim.2016. 09.011

117. Lucas CL, Zhang Y, Venida A, Wang Y, Hughes J, McElwee J, et al. Heterozygous splice mutation in PIK3R1 causes human immunodeficiency with lymphoproliferation due to dominant activation of PI3K. J Exp Med (2014) 211(13):2537-47. doi:10.1084/jem.20141759

118. Olbrich P, Lorenz M, Cura Daball P, Lucena JM, Rensing-Ehl A, Sanchez B, et al. Activated PI3Kdelta syndrome type 2: two patients, a novel mutation, and review of the literature. Pediatr Allergy Immunol (2016) 27(6):640-4. doi:10.1111/pai.12585

119. Elkaim E, Neven B, Bruneau J, Mitsui-Sekinaka K, Stanislas A, Heurtier L, et al. Clinical and immunologic phenotype associated with activated phosphoinositide 3-kinase delta syndrome 2: a cohort study. J Allergy Clin Immunol (2016) 138(1):210-8.e9. doi:10.1016/j.jaci.2016.03.022 
120. Kuhlen M, Honscheid A, Loizou L, Nabhani S, Fischer U, Stepensky P, et al. De novo PIK3R1 gain-of-function with recurrent sinopulmonary infections, long-lasting chronic CMV-lymphadenitis and microcephaly. Clin Immunol (2016) 162:27-30. doi:10.1016/j.clim.2015.10.008

121. Lougaris V, Faletra F, Lanzi G, Vozzi D, Marcuzzi A, Valencic E, et al. Altered germinal center reaction and abnormal $\mathrm{B}$ cell peripheral maturation in PI3KR1-mutated patients presenting with HIGM-like phenotype. Clin Immunol (2015) 159(1):33-6. doi:10.1016/j.clim.2015.04.014

122. Petrovski S, Parrott RE, Roberts JL, Huang H, Yang J, Gorentla B, et al. Dominant splice site mutations in PIK3R1 cause hyper IgM syndrome, lymphadenopathy and short stature. J Clin Immunol (2016) 36(5):462-71. doi:10.1007/s10875-016-0281-6

123. Bravo Garcia-Morato M, Garcia-Minaur S, Molina Garicano J, Santos Simarro F, Del Pino Molina L, Lopez-Granados E, et al. Mutations in PIK3R1 can lead to APDS2, SHORT syndrome or a combination of the two. Clin Immunol (2017) 179:77-80. doi:10.1016/j.clim.2017.03.004

124. Saettini F, Pelagatti MA, Sala D, Moratto D, Giliani S, Badolato R, et al. Early diagnosis of PI3Kdelta syndrome in a 2 years old girl with recurrent otitis and enlarged spleen. Immunol Lett (2017) 190:279-81. doi:10.1016/j. imlet.2017.08.021

125. Buchbinder D, Seppanen M, Rao VK, Uzel G, Nugent D. Clinical challenges: identification of patients with novel primary immunodeficiency syndromes. J Pediatr Hematol Oncol (2017). doi:10.1097/MPH.0000000000001003

126. Elgizouli M, Lowe DM, Speckmann C, Schubert D, Hülsdünker J, Eskandarian Z, et al. Activating PI3K $\delta$ mutations in a cohort of 669 patients with primary immunodeficiency. Clin Exp Immunol (2016) 183(2):221-9. doi:10.1111/cei.12706

127. Chiriaco M, Brigida I, Ariganello P, Di Cesare S, Di Matteo G, Taus F, et al. The case of an APDS patient: defects in maturation and function and decreased in vitro anti-mycobacterial activity in the myeloid compartment. Clin Immunol (2017) 178:20-8. doi:10.1016/j.clim.2015.12.008

128. Crank MC, Grossman JK, Moir S, Pittaluga S, Buckner CM, Kardava L, et al. Mutations in PIK3CD can cause hyper IgM syndrome (HIGM) associated with increased cancer susceptibility. J Clin Immunol (2014) 34(3):272-6. doi:10.1007/s10875-014-0012-9

129. Hartman HN, Niemela J, Hintermeyer MK, Garofalo M, Stoddard J, Verbsky JW, et al. Gain of function mutations of PIK3CD as a cause of primary sclerosing cholangitis. J Clin Immunol (2015) 35(1):11-4. doi:10.1007/ s10875-014-0109-1

130. Takeda AJ, Zhang Y, Dornan GL, Siempelkamp BD, Jenkins ML, Matthews HF, et al. Novel PIK3CD mutations affecting N-terminal residues of p110delta cause activated PI3Kdelta syndrome (APDS) in humans. J Allergy Clin Immunol (2017) 140(4):1152-6.e10. doi:10.1016/j.jaci.2017.03.026

131. Rae W, Ramakrishnan KA, Gao Y, Ashton-Key M, Pengelly RJ, Patel SV, et al. Precision treatment with sirolimus in a case of activated phosphoinositide 3-kinase delta syndrome. Clin Immunol (2016) 171:38-40. doi:10.1016/ j.clim.2016.07.017

132. Lucas CL, Chandra A, Nejentsev S, Condliffe AM, Okkenhaug K. PI3K delta and primary immunodeficiencies. Nat Rev Immunol (2016) 16(11): 702-14. doi:10.1038/nri.2016.93
133. Gardiner CM, Finlay DK. What fuels natural killers? Metabolism and NK cell responses. Front Immunol (2017) 8:367. doi:10.3389/fimmu.2017. 00367

134. Donnelly RP, Loftus RM, Keating SE, Liou KT, Biron CA, Gardiner CM, et al. mTORC1-dependent metabolic reprogramming is a prerequisite for NK cell effector function. J Immunol (2014) 193(9):4477-84. doi:10.4049/ jimmunol.1401558

135. Hoegenauer K, Soldermann N, Zecri F, Strang RS, Graveleau N, Wolf RM, et al. Discovery of CDZ173 (Leniolisib), representing a structurally novel class of PI3K delta-selective inhibitors. ACS Med Chem Lett (2017) 8(9): 975-80. doi:10.1021/acsmedchemlett.7b00293

136. Rao VK, Webster S, Dalm V, Sediva A, van Hagen PM, Holland S, et al. Effective "activated PI3Kdelta syndrome"-targeted therapy with the PI3Kdelta inhibitor leniolisib. Blood (2017) 130(21):2307-16. doi:10.1182/ blood-2017-08-801191

137. Eng C. PTEN: one gene, many syndromes. Hum Mutat (2003) 22(3):183-98. doi:10.1002/humu.10257

138. Trotta R, Parihar R, Yu J, Becknell B, Allard J II, Wen J, et al. Differential expression of SHIP1 in CD56 $6^{\text {bright }}$ and CD $56^{\text {dim }} \mathrm{NK}$ cells provides a molecular basis for distinct functional responses to monokine costimulation. Blood (2005) 105(8):3011-8. doi:10.1182/blood-2004-10-4072

139. Galandrini R, Tassi I, Mattia G, Lenti L, Piccoli M, Frati L, et al. SH2containing inositol phosphatase (SHIP-1) transiently translocates to raft domains and modulates CD16-mediated cytotoxicity in human NK cells. Blood (2002) 100(13):4581-9. doi:10.1182/blood-2002-04-1058

140. Benoit L, Wang X, Pabst HF, Dutz J, Tan R. Defective NK cell activation in X-linked lymphoproliferative disease. J Immunol (2000) 165(7):3549-53. doi:10.4049/jimmunol.165.7.3549

141. Tassi I, Cella M, Gilfillan S, Turnbull I, Diacovo TG, Penninger JM, et al. p110gamma and p110delta phosphoinositide 3-kinase signaling pathways synergize to control development and functions of murine NK cells. Immunity (2007) 27(2):214-27. doi:10.1016/j.immuni.2007.07.014

142. Clayton E, Bardi G, Bell SE, Chantry D, Downes CP, Gray A, et al. A crucial role for the p110delta subunit of phosphatidylinositol 3-kinase in B cell development and activation. J Exp Med (2002) 196(6):753-63. doi:10.1084/ jem.20020805

Conflict of Interest Statement: The author declares that the research was conducted in the absence of any commercial or financial relationships that could be construed as a potential conflict of interest.

The reviewer TP and the handling editor declared their shared affiliation.

Copyright (C) 2018 Mace. This is an open-access article distributed under the terms of the Creative Commons Attribution License (CC BY). The use, distribution or reproduction in other forums is permitted, provided the original author(s) and the copyright owner are credited and that the original publication in this journal is cited, in accordance with accepted academic practice. No use, distribution or reproduction is permitted which does not comply with these terms. 